\title{
Groundwater Quality in the Madera and Chowchilla Subbasins of the San Joaquin Valley, California
}

Groundwater provides more than $\mathbf{4 0}$ percent of California's drinking water. To protect this vital resource, the State of California created the Groundwater Ambient Monitoring and Assessment (GAMA) Program. The Priority Basin Project of the GAMA Program provides a comprehensive assessment of the State's untreated groundwater quality and increases public access to groundwater-quality information. The Madera and Chowchilla subbasins of the San Joaquin Valley constitute one of the study units being evaluated.

\section{The Madera-Chowchilla Study Unit}

The Madera-Chowchilla study unit is about 860 square miles and consists of the Madera and Chowchilla groundwater subbasins of the San Joaquin Valley Basin (California Department of Water Resources, 2003; Shelton and others, 2009). The study unit has hot, dry summers and cool, moist winters. Average annual rainfall ranges from 11 to 15 inches, most of which occurs between November and February. The main surfacewater features in the study unit are the San Joaquin, Fresno, and Chowchilla Rivers, and the Madera and Chowchilla canals. Land use in the study unit is about 69 percent (\%) agricultural, 28\% natural (mainly grasslands), and 3\% urban. The primary crops are orchards and vineyards. The largest urban area is the city of Madera.

The primary aquifer system is defined as those parts of the aquifer corresponding to the perforated intervals of wells listed in the California Department of Public Health (CDPH) database. In the Madera-Chowchilla study unit, these wells typically are drilled to depths between 200 and 800 feet, consist of a solid casing from land surface to a depth of about 140 to 400 feet, and are perforated below the solid casing. Water quality in the primary aquifer system may differ from that in the shallower and deeper parts of the aquifer system.

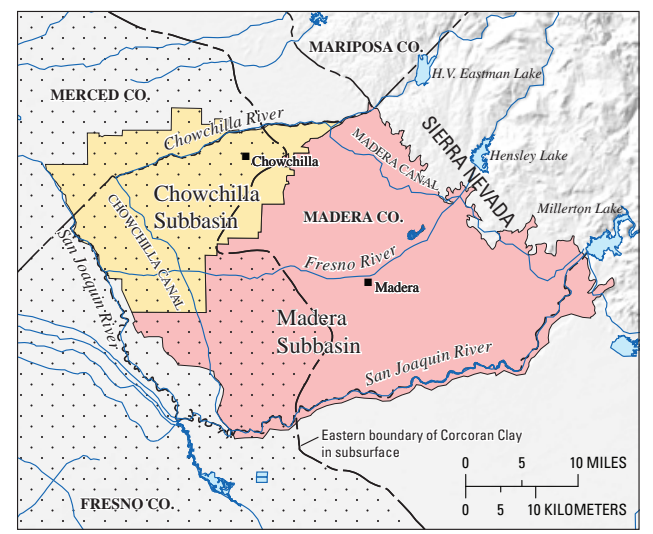

The primary aquifer system in the study unit consists of Quaternary-age alluvial-fan and fluvial deposits that were formed by the rivers draining the Sierra Nevada. Sediments consist of gravels, sands, silts, and clays and generally are coarser closest to the Sierra Nevada and become finer towards the center of the basin. The structure and composition of the deposits in the Madera-Chowchilla study unit are different from those in other parts of the eastern San Joaquin Valley because the Fresno and Chowchilla Rivers primarily drain the Sierra Nevada foothills, whereas the larger rivers drain higher elevations with greater sediment supply. These differences in the sources of sediments are important because they may affect the groundwater chemistry and the physical structure of the sedimentary deposits. Some of the clay layers are lacustrine deposits, the most extensive of which, the Corcoran Clay, underlies the western part of the study unit and divides the primary aquifer system into an unconfined to semi-confined upper system and a largely confined lower system.

Regional lateral flow of groundwater is southwest towards the valley trough. Irrigation return flows are the major source of groundwater recharge, and groundwater pumping is the major source of discharge. Groundwater on a lateral flow path may be repeatedly extracted by pumping wells and reapplied at the surface multiple times before reaching the valley trough, resulting in a substantial component of downward vertical flow (Burow and others, 2004; Phillips and others, 2007; Faunt, 2009). This flow pattern enhances movement of water from shallow depths to the primary aquifer system.

\section{Overview of Water Quality}

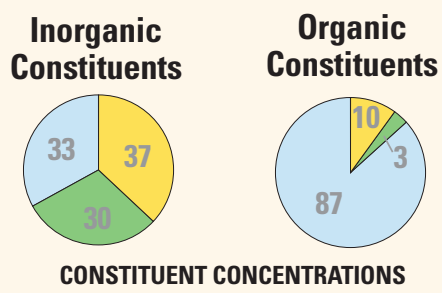

High $\bigcirc$ Moderate $\bigcirc$ Low or not detected

Pie charts illustrate the proportion of the primary aquifer system with concentrations in specified categories.

GAMA’s Priority Basin Project evaluates the quality of untreated groundwater. However, for context, benchmarks established for drinkingwater quality are used for comparison. Benchmarks and definitions of high, moderate, and low concentrations are discussed in the inset box on page 3 .

Many inorganic constituents occur naturally in groundwater. The concentrations of inorganic constituents can be affected by natural processes as well as by human activities. In the Madera-Chowchilla study unit, one or more inorganic constituents were present at high concentrations in about $37 \%$ of the primary aquifer system and at moderate concentrations in about $30 \%$.

Human-made organic constituents are present in products used in the home, business, industry, and agriculture. Organic constituents can enter the environment through normal usage, spills, or improper disposal. In this study unit, one or more organic constituents were present at high concentrations in about $10 \%$ of the primary aquifer system and at moderate concentrations in about 3\%. 


\section{RESULTS: Groundwater Quality in the Madera-Chowchilla Study Unit}

\section{INORGANIC CONSTITUENTS}

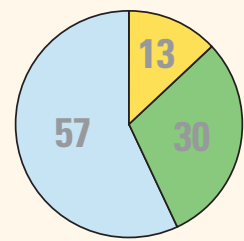

Trace

Elements

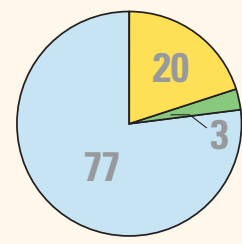

\section{Radioactive} Constituents
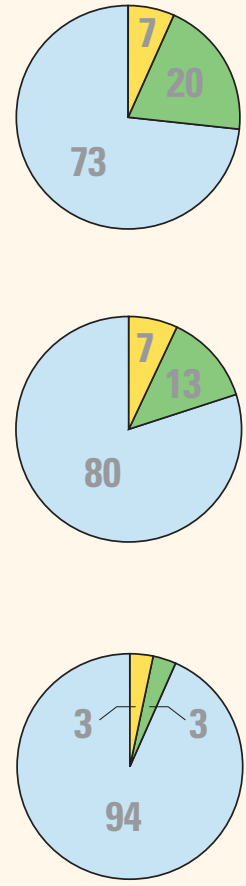

\section{Manganese}

SPECIAL-INTEREST CONSTITUENT

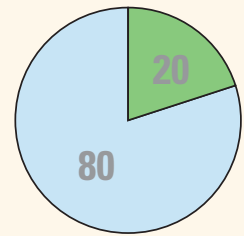

\section{Total Dissolved Solids}

\section{Inorganic Constituents with Human-Health Benchmarks}

Trace elements are naturally present in the minerals in rocks and soils, and in the water that comes into contact with those materials. In the Madera-Chowchilla study unit, one or more trace elements were present at high concentrations in about $13 \%$ of the primary aquifer system, and at moderate concentrations in about $30 \%$. Arsenic and vanadium were the trace elements that most frequently occurred at high concentrations, in about $13 \%$ and about $3 \%$ of the primary aquifer system, respectively. Barium and strontium also were detected at high concentrations, but only in less than $2 \%$ of the primary aquifer system.

Radioactivity is the emission of energy or energetic particles during spontaneous decay of unstable atoms. Humans are exposed to small amounts of natural radioactivity every day. Most of the radioactivity in groundwater comes from decay of naturally occurring uranium and thorium in minerals in the sediments of the aquifer. In the Madera-Chowchilla study unit, radioactive constituents occurred at high levels in about $20 \%$ of the primary aquifer system, and at moderate levels in about $3 \%$. Gross alpha particle activity and uranium activity were the radioactive constituents that most frequently occurred at high levels.

Nutrients, such as nitrogen, are naturally present at low concentrations in groundwater. High and moderate concentrations generally occur as a result of human activities. Common sources of nutrients include fertilizers applied to crops and landscaping, seepage from septic systems, and human and animal waste. In the Madera-Chowchilla study unit, nitrate was present at high concentrations in about $7 \%$ of the primary aquifer system and at moderate concentrations in about $20 \%$.

\section{Inorganic Constituents with Non-Health Benchmarks}

(Not included in water-quality overview charts shown on the front page)

Some constituents affect the aesthetic properties of water, such as taste, color, and odor, or may create nuisance problems, such as staining and scaling. The State of California has a recommended and an upper limit for total dissolved solids (TDS) in drinking water. Groundwater naturally contains TDS as a result of the weathering and dissolution of minerals in soils. In the Madera-Chowchilla study unit, TDS was present at high concentrations (greater than the upper limit) in about $7 \%$ of the primary aquifer system, and at moderate concentrations (between the recommended and upper limit) in about $13 \%$.

Manganese occurs naturally in minerals, and anoxic conditions (low amounts of dissolved oxygen) in groundwater may result in the release of manganese from minerals into groundwater. Manganese was present at high concentrations and moderate concentrations, each, in about $3 \%$ of the primary aquifer system.

\section{Perchlorate}

(Not included in water-quality overview charts shown on the front page)

Perchlorate is an inorganic constituent that has been regulated in California drinking water since 2007. It is an ingredient in rocket fuel, fireworks, safety flares, and some fertilizers, and also occurs naturally at low concentrations in groundwater. In the MaderaChowchilla study unit, perchlorate was not detected at high concentrations in the primary aquifer system but was detected at moderate concentrations in about $20 \%$ of the primary aquifer system. 


\section{RESULTS: Groundwater Quality in the Madera-Chowchilla Study Unit}

\section{ORGANIC CONSTITUENTS}

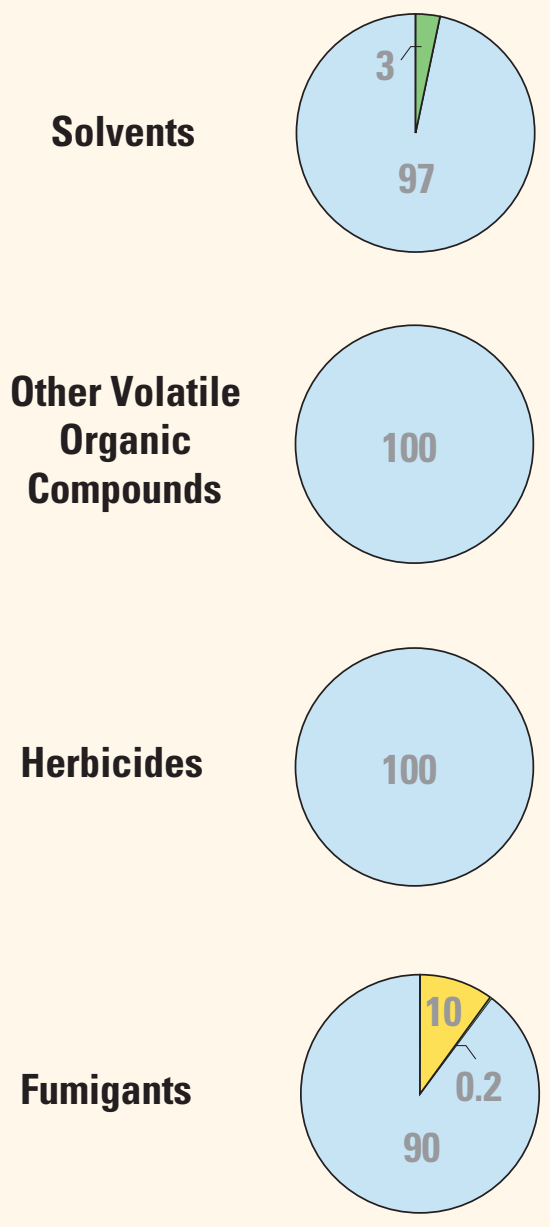

\section{Organic Constituents}

The Priority Basin Project uses laboratory methods that can detect the presence of volatile organic compounds (VOCs) and pesticides at low concentrations, far below human-health benchmarks. VOCs and pesticides detected at these low concentrations can be used to help trace water pathways from the landscape into the aquifer system.

\section{Volatile Organic Compounds with Human-Health Benchmarks}

VOCs are in many household, commercial, industrial, and agricultural products and are characterized by their tendency to volatilize (evaporate) into the air. Solvents are used for a number of purposes, including manufacturing and cleaning. In the Madera-Chowchilla study unit, solvents were not present at high concentrations in the primary aquifer system. Solvents were present at moderate concentrations in about 3\% of the primary aquifer system and at low concentrations (or not detected) in about $97 \%$.

Other VOCs include trihalomethanes, gasoline additives, refrigerants, and organic synthesis reagents. Other VOCs were not detected at high or moderate concentrations in the primary aquifer system, and trihalomethanes were detected at low concentrations. Trihalomethanes can form during disinfection of water supplies and may enter groundwater by the infiltration of landscape irrigation water, leakage from septic and sewage systems, or use of disinfection solutions in wells. Fumigants, a class of VOCs in agricultural products and a type of pesticide, are discussed with pesticides.

\section{Pesticides with Human-Health Benchmarks}

Pesticides, including herbicides, insecticides, and fumigants, are applied to crops, gardens, lawns, around buildings, and along roads to help control unwanted vegetation (weeds), insects, fungi, and other pests. Fumigants are of special interest in California because of their historical use to control nematodes in vineyards and orchards.

In the Madera-Chowchilla study unit, fumigants were present at high concentrations in about $10 \%$ of the primary aquifer system, and at moderate concentrations in $0.2 \%$. The fumigant detected at high concentrations was 1,2-dibromo-3-chloropropane (DBCP). DBCP was not detected at moderate or low concentrations. The use of DBCP as a soil fumigant was discontinued in California in 1977. Herbicides were not detected at high or moderate concentrations in the primary aquifer system, but were frequently detected at low concentrations. Insecticides that are not fumigants were not detected.

\section{BENCHMARKS FOR EVALUATING GROUNDWATER QUALITY}

GAMA’s Priority Basin Project uses benchmarks established for drinking water to provide context for evaluating the quality of untreated groundwater. After withdrawal, groundwater may be disinfected, filtered, mixed, and exposed to the atmosphere before being delivered to consumers. Federal and California regulatory benchmarks for protecting human health (Maximum Contaminant Level, MCL) were used when available. Otherwise, non-regulatory benchmarks for protecting aesthetic properties, such as taste and odor (Secondary Maximum Contaminant Level, SMCL), and non-regulatory benchmarks for protecting human health (Notification Level, NL, and Lifetime Health Advisory, HAL) were used.

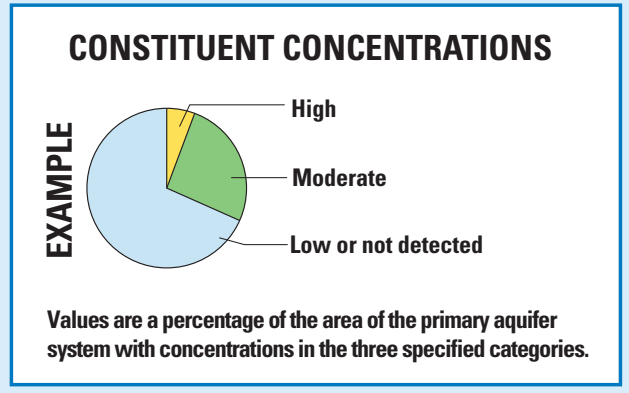

\section{High, moderate, and low concentrations are defined relative to benchmarks}

Concentrations are considered high if they are greater than a benchmark. For inorganic constituents, concentrations are moderate if they are greater than one-half of a benchmark. For organic and special-interest constituents, concentrations are moderate if they are greater than one-tenth of a benchmark; this lower threshold was used because organic constituents generally are less prevalent and have smaller concentrations relative to benchmarks than inorganic constituents. Low concentrations include nondetections and values less than moderate concentrations. Methods for evaluating water quality are discussed by Shelton and others (2012). 


\section{Factors that Affect Groundwater Quality}

In the Madera-Chowchilla study unit, uranium (17\%), arsenic (13\%), and nitrate (7\%) were the inorganic constituents that were most frequently detected at high concentrations in the primary aquifer system. High and moderate concentrations of uranium and nitrate were found in shallower wells (depth to top of well perforations less than 235 feet), and in wells located in the western part of the study unit above the Corcoran Clay. Groundwater with elevated concentrations of uranium and nitrate was classified predominantly as modern or mixed age. Tritium and carbon-14 dating were used to define groundwater age: modern, recharged since 1950; pre-modern, recharged before 1950; and mixed, containing modern and pre-modern waters. Jurgens and others (2009) showed that downward-moving irrigation-return water that recharges aquifers in the Eastern San Joaquin Valley contains high concentrations of bicarbonate. The bicarbonate dissolves naturally occurring uranium off of the sediments, and recharge transports the uranium to the depths of the primary aquifer system. Nitrate derived from human activities on the land surface would also be transported into the primary aquifer system by this recharge process.

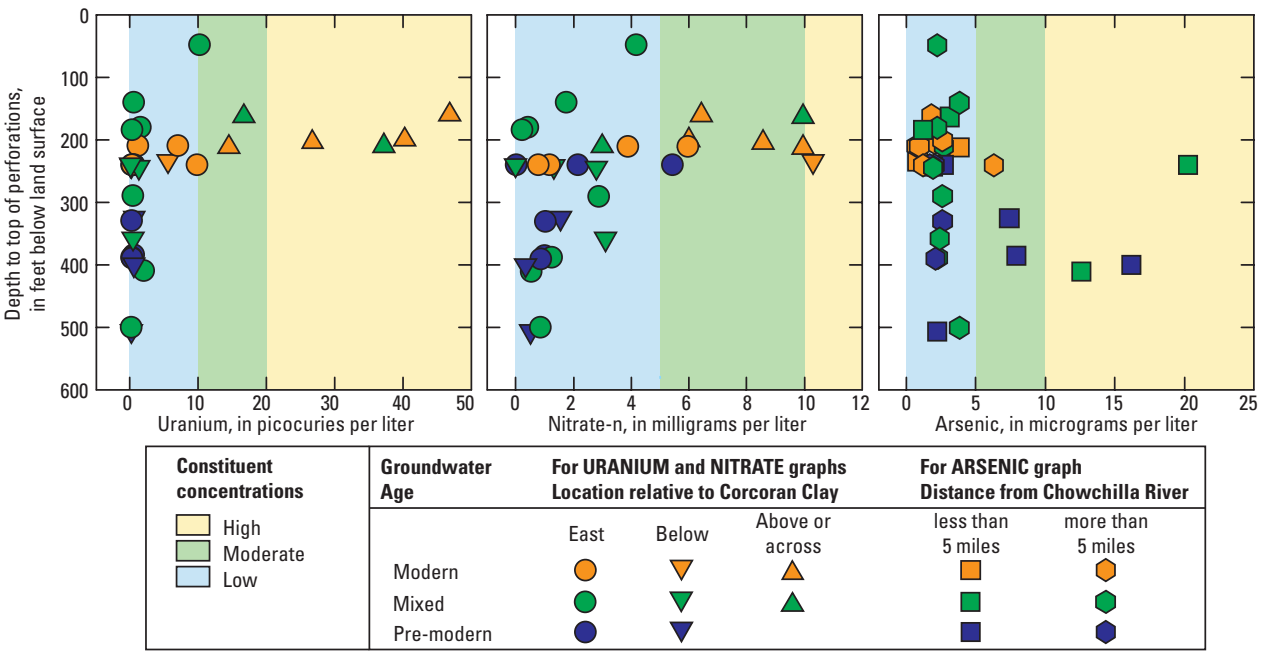

In contrast, high and moderate concentrations of arsenic were detected in deeper wells (depth to top of well perforations greater than 235 feet), and in groundwater classified as pre-modern or mixed age. Most of the moderate and high arsenic concentrations were in wells located within 5 miles of the Chowchilla River. Sediments along the Chowchilla River likely are different from those along the Fresno and San Joaquin Rivers.

\section{By Jennifer L. Shelton, Miranda S. Fram, and Kenneth Belitz}

\section{REFERENCES}

Burow, K.R., Shelton, J.L., Hevesi, J.A., and Weissmann, G.S., 2004, Hydrogeologic characterization of the Modesto area, San Joaquin Valley, California: U.S. Geological Survey Scientific Investigations Report 2004-5232, 54 p.

California Department of Water Resources, 2003, California’s groundwater: California Department of Water Resources Bulletin 118, 246 p., accessed July 1, 2011, at http://www.water.ca.gov/ groundwater/bulletin118/update2003.cfm/

Faunt, C.C., ed., 2009, Groundwater availability of the Central Valley aquifer, California: U.S. Geological Survey Professional Paper 1766, 225 p.

Jurgens, B.C., Fram, M.S., Belitz, K., Burow, K.R., and Landon, M.K., 2009, Effects of groundwater development on uranium-Central Valley, California, USA: Ground Water, v. 48, no. 6, p. 913-928.

Phillips, S.P., Green, C.T., Burow, K.R., Shelton, J.L., and Rewis, D.L., 2007, Simulation of multiscale ground-water flow in part of the northeastern San Joaquin Valley, California: U.S. Geological Survey Scientific Investigations Report 2007-5009, 43 p.

Shelton, J.L., Fram, M.S., and Belitz, K., 2009, Groundwater-quality data for the Madera-Chowchilla study unit, 2008-Results from the California GAMA Program: U.S. Geological Survey Data Series 455, 80 p. (Also available at http://pubs.usgs.gov/ds/455/.)

Shelton, J.L., Fram, M.S., Belitz, K., and Jurgens, B.C., 2012, Status and understanding of groundwater quality in the Madera-Chowchilla study unit, 2008: U.S. Geological Survey Scientific Investigations Report 2012-5094, 86 p. (Also available at http://pubs.usgs.gov/ $\underline{\operatorname{sir} / 2012 / 5094 .)}$

\section{Priority Basin Assessments}

GAMA’s Priority Basin Project (PBP) assesses water quality in that part of the aquifer system used for drinking water, primarily public supply. Water quality in the primary aquifer system may differ from that in the deep parts of the aquifer, or from that in the shallower parts, which are being assessed by GAMA's Domestic Well Project. Ongoing assessments are being conducted in more than 120 basins throughout California.

The PBP assessments are based on a comparison of constituent concentrations in untreated groundwater with benchmarks established for the protection of human health and for aesthetic concerns. The PBP does not evaluate the quality of drinking water delivered to consumers.

The PBP uses two scientific approaches for assessing groundwater quality. The first approach uses a network of wells to statistically assess the status of groundwater quality. The second approach combines water-quality, hydrologic, geographic, and other data to help assess the factors that affect water quality. In the Madera-Chowchilla study unit, data were collected by the PBP in 2008 and from the CDPH database for 2005-2008. The PBP includes chemical analyses not generally available as part of regulatory compliance monitoring, including measurements at concentrations much lower than human-health benchmarks and measurements of constituents that can be used to trace the sources and movement of groundwater.

\section{For more information}

Technical reports and hydrologic data collected for the GAMA Program may be obtained from:

\section{GAMA Project Chief}

U.S. Geological Survey

California Water Science Center 4165 Spruance Road, Suite 200

San Diego, CA 92101

Telephone number: (619) 225-6100

WEB: http://ca.water.usgs.gov/gama

GAMA Program Unit

State Water Resources Control Board Division of Water Quality

PO Box 2231, Sacramento, CA 95812

Telephone number: (916) 341-5779 WE B: http://www.waterboards.ca.gov/gama 